\title{
Note on the Petiole of Zygopteris Grayi, Will.
}

BY

R. KIDSTON, LL.D., F.R.S.

With Plate XXXIV.

TNTIL the publication of Dr. Paul Bertrand's 'Études sur la fronde des Zygoptéridées' last year, in which he unites Zygopteris bibractensis var. Westphalica, P. Bertrand, ${ }^{1}$ with Zygopteris Grayi, Will. sp., as its petiole, ${ }^{2}$ I was under the impression that it was common knowledge that Zygopteris di-upsilon, Will., was the petiole of that stem.

On communicating with Dr. Scott on this subject, I find I have been mistaken in believing that this relationship between Zygopteris Grayi and $Z$. di-upsilon was generally known, and on his suggestion the present note is written.

Although Zygopteris Grayi has been more or less fully described by several botanists, ${ }^{3}$ there are certain points in connexion with the socalled 'axillary shoot' which appear still to await description, and as this is intimately connected with the leaf-trace, even at the risk of repetition it seems desirable to describe the relation of the petiole to the so-called 'axillary shoot' and to follow the former until it is given off and free in the cortex.

As the term 'axillary shoot' seems to me very misleading, I must anticipate, for reasons which will be subsequently stated, and substitute the term 'branch' for this structure in the following description.

The stem-stele of Zygopteris Grayi is more or less distinctly stellate in transverse section, but the length of the five arms varies in prominence,

1 The Zygopteris bibractensis of Williamson, but possibly not the Zygopteris bibractensis of Renault. Ann. des Sci. Nat., $5^{\text {e }}$ sér., Bot. vol. xii, p. 17 I, Pl. IX, Figs. I 7 and 18.

2 P. Bertrand, Études sur la fronde des Zygoptéridées, pp. 106, 107, 22.

3 I889. Rachiopteris Grayi, Will., Mem. xv, Phil. Trans., vol. clxxx (1889), B., p. I56, P1. I, Figs. 1, 2, 3, 4 (? Fig. 5) ; P1. II, Fig. 5 A.

I9co. Zygopteris Grayi, Scott, Studies in Fossil Bot., Ist ed., p. 278, Figs. 97 and 98 ; 2nd ed., vol. i, p. 306, Figs. II 5 and II6, 1908.

1908. Zygopteris Grayi, Tansley, Evolution of the Filicinean Vascular System, p. I6, Fig. 6. 1909. Ankyropteris Grayi, P. Bertrand, Études sur la fronde des Zygoptéridées, p. 107, P1. XI, Fig. 78 .

1880. Rachiopteris di-upsilon, Mem. x, Phil. Trans., pp. 537-8, Pl. XXI, Figs. 90 and 9I. 1909. Etapteris diupsilon, P. Bertrand, 1. c., p. I48, P1. I, Fig. 6; Pl. XVI, Fig. I Io.

[Annals of Botany, Vol. XXIV. No. XCIV. April, 19ı.] 
according to the state at which they have arrived in giving off branches; that which has just given off a branch being shortest, while that from which one is just about to be given off is longest. If one of the stele arms in the latter condition be examined, it will be seen that its extremity is subtriangular in form, with the distal margin always straight, and terminating in two lateral horn-like points (Fig. I). Fig. 2 shows a branch just given off. The central area is occupied by a mixed pith, composed of parenchyma and small tracheae, and is a continuation of the mixed pith of the stem. ${ }^{1}$ This is surrounded by a zone of tracheae, the adaxial portion being formed of one to three rows of moderately large tracheae, while the abaxial portion contains generally one-rarely two rows. The extremity of the lateral horns usually consists of a few small tracheae, which hold a special relation to the roots. In all essentials the 'branch' at this stage resembles the stem-stele with the exception of the five prominent angles.

As the 'branch' travels outwards and upwards through the cortex it assumes a slightly more oval form, and the 'horns' of small tracheae disappear, though it still contains a mixed pith, and possesses all the essential characters of its parent stem (Fig. 3). At this stage, the xylem of the abaxial side of the branch still usually possesses only a single row of tracheae.

The beginning of the formation of the petiole trace is seen at Fig. 4. This stage immediately follows that described and seen at Fig. 3. The abaxial side of the branch shows a slight increase in the thickness of the xylem, and from each of the abaxial rounded angles tracheae, mostly of a size similar to those forming the branch-stele, begin to appear (Fig. $\left.4, a^{\prime}, a^{\prime}\right)$.

Traced higher up these two groups unite and form a bar placed tangentially to the axis of the branch as seen in Fig. $5, a$, where it is still attached to the branch. Here the pith seems entirely to have disappeared from the branch-stele. The specimen shows a very small clear space in the centre of the axis, but this has much more the appearance of a break in the xylem than a space left by the decay of parenchyma. The specimen is, however, too imperfectly preserved for a definite conclusion on this point.

I have not been able to observe on the specimens at my disposal the actual union of the two groups of tracheae which form the bar or the very early stages of the arm development, but from the examples given at Figs. 4 and 5, there can be little doubt as to the intermediate stages of development which succeed each other.

At Fig. 6 the petiole trace has become quite free from the branch, and advanced some distance outwards as a free organ. The rows of tracheae on the abaxial side of Figs. 2, 3, and 4 have much increased in thickness, though the branch still shows an opening in the central area, but the manner in which fragments of walls of the surrounding tracheae project inwards

1 See Kidston and Gwynne-Vaughan, Trans. Roy. Soc., Edin., vol, xlvii, p. 468, I9ro. 
towards the opening rather confirms the opinion already stated as to the branch possessing a solid protostelic structure, though here again the preservation of the specimen leaves the matter in doubt.

The petiole trace seen at Fig. 6 possesses all the essential characters of Zygopteris di-upsilon, Williamson. It is of course much smaller than the trace in the fully developed petiole; that seen at Fig. 6 only measuring $\mathbf{1 . 7} \mathrm{mm}$. in a direction parallel with the cross-bar, while the measurement of the same portion of the petiole trace in the type specimen of $Z$.di-upsilon is $4.75 \mathrm{~mm}$. It is, however, an ascertained fact that the petiole trace increases in size in its passage outwards, and does not seem to attain its full dimensions even in the immediate base of the free petiole.

That the petiole shown at Fig. 6 and still contained within the cortex of Zygopteris Grayi cannot be an immature condition of the petiole which Williamson identified as Zygopteris bibractensis, Renault, and which has now been distinguished as $Z$. bibractensis var. Westphalica by Dr. Paul Bertrand, ${ }^{1}$ is seen from its narrow straight bar and the long thin arms, scarcely incurved, and without any indication of the external band of small tracheae on the outside of the arms, which is so distinctive a feature in the $Z$. bibractensis type of petiole. The very much incurved arms and curved cross-bar of this latter species are also absent from the petiole trace of our specimens. On the other hand, all the characters of the petiole trace found in the cortex of $Z$. Grayi are identical with those of $Z$. di-upsilon.

It might be pointed out that the petiole which Williamson figures on Pl. I, Fig. 4 of his Memoir xv, is referable to Zygopteris di-upsilon, and this I think was his opinion, for he refers to it as 'a similar Zygopteroid petiolar bundle' to that he has described in the cortex of $Z$. Grayi. ${ }^{2}$

The morphology of the so-called 'axillary shoot' which I regard simply as a branch must shortly be considered.

Stenzel was the first to observe this so-called 'axillary shoot', ${ }^{3}$ but later it was also recognized by Williamson, who described it as a 'circular aberrant organ' which he regarded as a branch, and this is the view that has been generally accepted, and the leaf-trace has been considered to arise from a division of the 'axillary shoot' into two unequal parts. It is thus described by Dr. Scott: 'As we follow the leaf-trace outwards through the cortex, we find that it divides into two strands, of very different form, both lying on the same radius. The outer of the two strands is the foliar bundle, which is continuous with the external side of the original triangular strand, while the inner strand is destined for the axillary shoot.' 4

In regard to the 'axillary shoot' in the Hymenophyllaceae, Tansley says: "The stem-like structure of the strand below the junction of the leaf

1 P. Bertrand, 1. c., p. 73 .

${ }^{2}$ Williamson, 1.c., p. ${ }^{5} 57$.

${ }^{3}$ Stenzel, Die Gattung Tubicaulis Cotta, pp. 35-6, 1889 .

${ }^{4}$ Studies in Fossil Botany, and ed., vol. i, p. 31 I, I908. 


\section{Kidston.-Note on the Petiole of Zygopteris Grayi, Will.}

and branch traces might of course be explained by the hypothesis that this basal portion is really a stem-structure on which the leaf is inserted, but this consideration, even if valid, will not apply to the structure of the petiole strand above its junction with the branch-strand. The whole of the phenomena, taken in conjunction with those of $T$. reniforme, appear to lend decided support to the interpretation of leaf-strand and stem-stele as primitive identical structures;' 1 and again further: 'We do actually find, in the Botryopterideae and Hymenophyllaceae, the base of the leaftrace exhibiting a structure which may be interpreted in this way.' ${ }^{2}$ In talking of Zygopteris it is stated: "The leaf-trace departs as an isodiametric strand which divides tangentially as it passes through the cortex, the inner half becoming the stele of the axillary shoot, while the outer becomes the petiolar strand. The latter has at first the form of a tangentially extended band....' 3 It is evident then that Tansley regards the petiole and the remainder of the 'axillary shoot' as two parts of a single organ, and this he believes to be cauline.

Dr. Scott, however, from the study of the stem of Zygopteris corrugata where the leaf-traces are given off direct from the stem, without the occurrence of any 'axillary shoot', speaks of them as 'rather of the nature of a dichotomy', and gives the note of warning that 'this fact raises the question whether, as has been suggested, the apparent axillary branching of other species (of Zygopteris) and of recent Hymenophyllaceae may not be a modified dichotomy, in which case the "undivided leaftrace" would really be the stele of the small branch, and the "subtending" leaf would belong to this branch and not to the main axis. The data are insufficient to settle the question, and for the present it seems better to keep up the distinction between the two kinds of branching.' ${ }^{4}$ That the explanation of the nature of the 'axillary shoot' given here by Dr. Scott is the correct one is fully borne out by the development of the leaf-trace of Zygopteris Grayi, Will.

In this species, no division of the so-called 'axillary shoot' takes place in the departure of the leaf-trace, but it arises from the periphery of that structure as an independent organ, and at no time partakes of the structure of the organ from which it arises. The so-called ' axillary shoot', till after the departure of the leaf-trace, retains a structure comparable with that possessed by the stem, and the only change which takes place in its structure is the possible loss of the pith, but this does not seem to occur until after the departure of the petiole, when it appears to be wholly formed of xylem, and assumes the condition of a solid protostele. As far as I have been able to observe, the petiole carries nothing of the branch with it, except it be a few tracheae from the two abaxial angles of the so-called

1 Tansley, Evolution of Filicinean Vascular Structure, p. 33. $\quad{ }^{2}$ Tansley, 1. c., p. II 5 .

${ }^{3}$ Ibid., p. 17 .

1 Scott, Studies, vol. i, and ed. p. 3 I 8 . 
'axillary shoot', which I believe is morphologically a branch which gives rise to, but which does not of its own tissue contribute to, the formation of the leaf-trace.

It may be further pointed out that Zygopteris Grayi is by no means the most primitive type of Zygopteris. In Zygopteris corrugata, according to Dr. Scott, there is no 'axillary shoot' in connexion with the leaf departure, and in the older Zygopteris (Diplolabis) Roemeri, Solms, from the culm, of which the stem was recently described by Mr. W. T. Gordon before the Royal Society of Edinburgh, ${ }^{1}$ the petioles arise directly from the solid protostele, and their steles assume the characteristic Zygopteroid form in their passage through the cortex.

The presence of a small stem from which the petioles arise, and the occurrence of a mixed pith in Zygopteris Grayi, would indicate that it has travelled some considerable distance from the primitive type of Zygopteroid structure. $^{2}$

1 Dec. 20, 1909.

2 Note.-Zyopteris (Ankyropteris) scandens, Stenzel (Die Gattung Tubicaulis Cotta, p. 3I, Pl. VI, Figs. 50-5, Pl. VII, Figs. 56-65, I889), has been considered by some botanists as synonymous with $Z$. Grayi, Will., but is essentially distinct from that plant and is easily distinguished by the form of its petiole trace. The cross-bar of $Z$. scandens is formed of two rows of much larger tracheae than those of $Z$. di-upsilon ( $=Z$. Grayi), where the cross-bar is seven or eight rows wide. The arms of $Z$. scandens are slightly incurved and do not possess the outward spreading form of those of $Z$. $d i$ upsilon, but above all, the abaxial arms of $Z$. scandens bend inwards towards each other and are shorter than the adaxial arms. The bar is also slightly curved, which gives the leaf-trace an inequilateral form; or, to put it in other words, the petiole trace of $Z$. scandens has only one plane of symmetry-the vertical, while that of $Z$. Grayi has two planes of symmetry-the vertical and horizontal. These two species cannot therefore be united. (See Stenzel, 1. c., Pl. VII, Fig. 63.)

\section{EXPLANATION OF PLATE XXXIV.}

Illustrating Dr. Kidston's paper on Zygopteris Grayi, Williamson.

[All figures are enlarged about 17 times.]

The * indicates the position of the axis of the stem.

Fig. I. From specimen contained in the Collection of the Manchester Museum, No. R. 443. Loc. Oldham. Hor. Halifax Hard Bed.

Fig. 2. From specimen contained in the Author's Collection, No. 308. Loc. Oldham.

Fig. 3. From specimen contained in the Collection of the Manchester Museum, No. R. 443. Loc. Oldham.

Fig. 4. From specimen contained in the Author's Collection, No. 308. $a^{\prime}, a^{\prime \prime}$, Bar of petiole. Loc. Oldham.

Fig. 5. From specimen contained in the collection of the Manchester Musenm, No. R. 44r. $a$, Bar of petiole; $b$, Branch. Loc. Sunfield, Oldham.

Fig. 6. From specimen contained in the Author's Collection, No. 305. b, Branch. Loc. Sunfield, Oldham.

My thanks are due to Professor Weiss, for kind permission to figure and describe the specimens contained in the Collection of the Manchester Museum. 


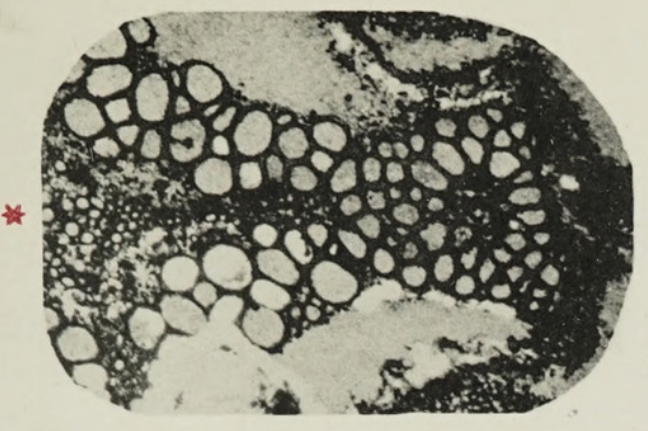

1.

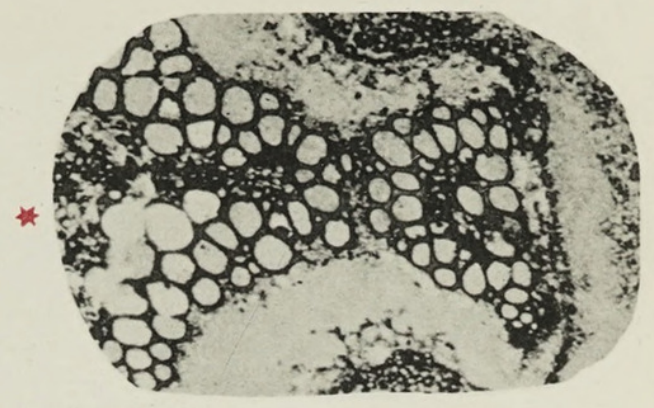

2.

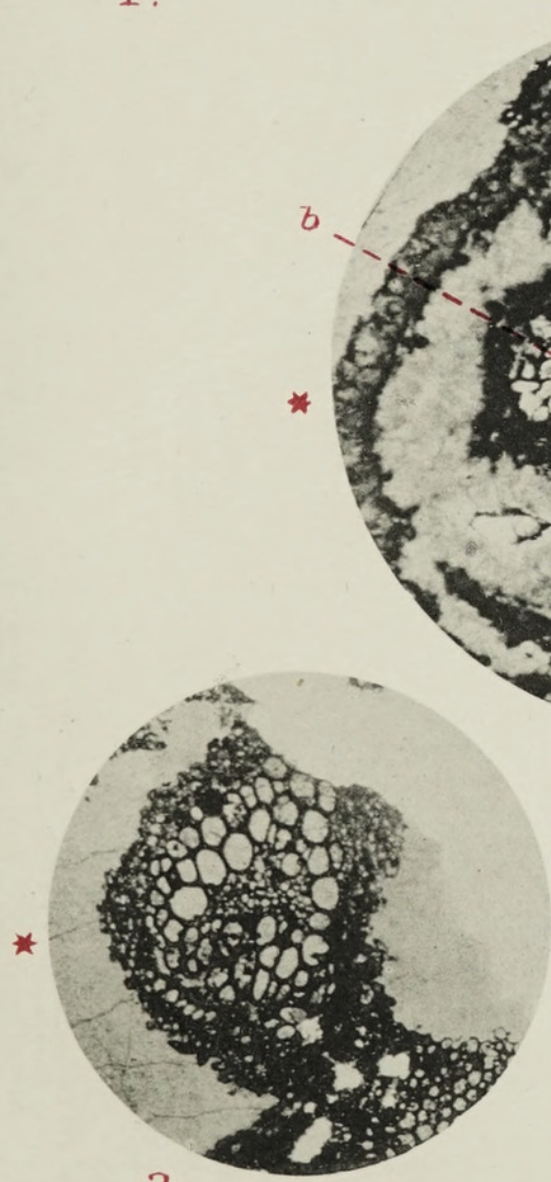

3.

6.
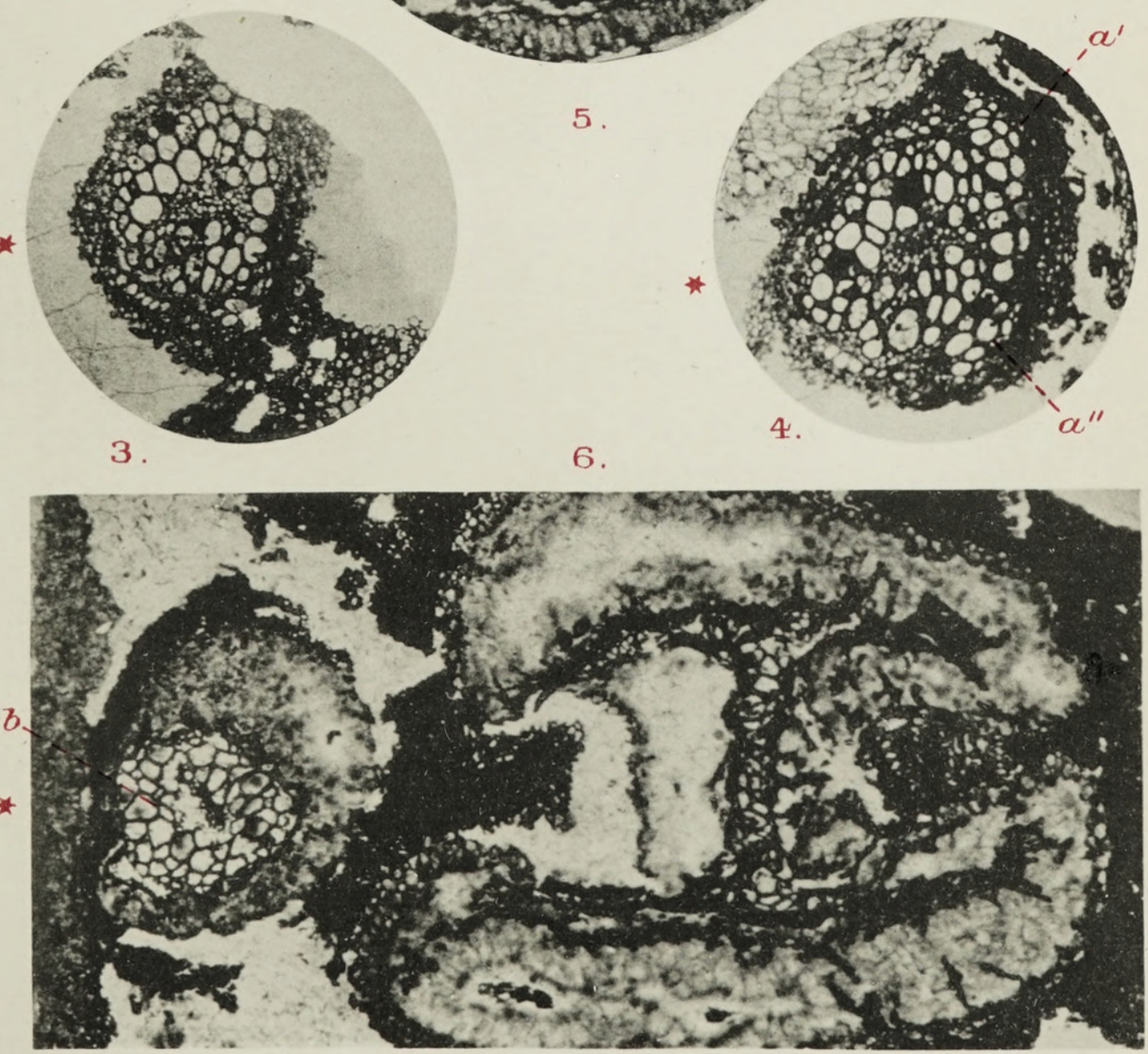

R. Kidston, photo.

KIDSTON-ZYGOPTERIS GAAYI Williamson. 


\section{$2 \mathrm{BHL}$ Biodiversity Heritage Library}

Kidston, R. 1910. "Note on the petiole of Zygopteris grayi, Will." Annals of botany 24, 451-455. https://doi.org/10.1093/oxfordjournals.aob.a089278.

View This Item Online: https://www.biodiversitylibrary.org/item/262605

DOI: https://doi.org/10.1093/oxfordjournals.aob.a089278

Permalink: https://www.biodiversitylibrary.org/partpdf/319786

\section{Holding Institution}

New York Botanical Garden, LuEsther T. Mertz Library

\section{Sponsored by}

BHL-SIL-FEDLINK

\section{Copyright \& Reuse}

Copyright Status: Public domain. The BHL considers that this work is no longer under copyright protection.

This document was created from content at the Biodiversity Heritage Library, the world's largest open access digital library for biodiversity literature and archives. Visit BHL at https://www.biodiversitylibrary.org. 